\title{
Preparation of Poly (N- Imidazolyl maleamic acid)
}

\author{
Firyal M. Ali, Khudheyer J. Kadem*, Firas A. Rahi ${ }^{* *}$ and Estabrak W. Gayadh ${ }^{* * *}$ \\ Department of Chemistry, College of Science, Al-Mustansiriyah University, Bagdad-Iraq. \\ *Department of Chemistry, College of Science, Babylon University, Babylon-Iraq. \\ Department of Pharmaceutical, Al-Mustansiriyah University, Bagdad-Iraq. \\ *** Department of Chemistry, College of Science, Al-Anbar University, Al-Anbar-Iraq.
}

\begin{abstract}
In this research preparation of poly (maleamic acide) which substituted with imidazole as a bioactive material is performed. It was prepared from reaction of maleic anhydride with imidazole and Ring opening of maleic anhydride by imidazole, then the substituted maleamic acid was polymerized by freeradical polymerization by using dibenzoylperoxide as initiator. The structure of synthesized polymer was confirmed by FTIR, UV. and ${ }^{1} \mathrm{H}-\mathrm{NMR}$ spectroscopes, The controlled release of imidazol units was studied in different $\mathrm{pH}$ values at $37{ }^{0} \mathrm{C}$. All physical properties of prepared polymer were measured.
\end{abstract}

Keywords: Preparation, N-Imidazolyl, maleamic acid.

\section{Introduction}

Imidazole is an organic compound with the formula $\mathrm{C}_{3} \mathrm{H}_{4} \mathrm{~N}_{2}$. This aromatic heterocyclic is a diazole and is classified as an alkaloid [1].

Imidazole is a 5-membered planar ring, which is soluble in water and other polar solvents. It exists in two equivalent tautomeric forms, $\quad 1 H$-imidazole and $3 H$-imidazole, because the hydrogen atom can be located on either of the two nitrogen atoms. Imidazole is a highly polar compound, as evidenced by a calculated dipole of 3.61므, and is entirely soluble in water. The compound is classified as aromatic due to the presence of a sextet of $\underline{\pi \text {-electrons, }}$, consisting of a pair of electrons from the protonated nitrogen atom and one from each of the remaining four atoms of the ring [2,3].

Imidazole incorporated into many important biological molecules. The most pervasive is the amino acid histidine [4], which has an imidazole side-chain, Histidine is present in many proteins and enzymes and plays a vital part in the structure and binding functions of hemoglobin [5,6].

Histidine can be decarboxylated to histamine, which is also a common biological compound. It is a component of the toxin that causes urticaria, which is another name for allergic hives [7]. One of the applications of imidazole is in the purification of histagged proteins in immobilized metal affinity[8].
Imidazole has became an important part of many pharmaceuticals. Synthetic imidazoles are present in many fungicides and antifungal antiprotozoal and antihypertensive medications. It found in tea leaves and coffee beans, that stimulates the central nervous system. It is present on the anticancer medication mereaptopurine, with combats leukemia by interfering with DNA activities [9].

Imidazol has been used extensively as a corrosion inhibitor on certain transition metals, such as copper. Preventing copper corrosion is important, especially in aqueous system, where the conductivity of the copper decreases due to corrosion. The thermostable polybenzimid azd contains imidazole fused to benzene ring and linked to a benzene and acts a fire retardant, it can also be found in various compounds that are used for photography and electronics [10]. Both the imidazole and amidine functionalities were introduced to construct an active site for catalytic ester hydrolyze.[11]. The imprinted polymers, having both the amidine and imidazole as functional groups [14], were expected to have improved hydrolytic activity compared with other imprinted polymers having the corresponding single functional group [12].

Synthesis and biological screening of some newly synthesized imidazole is divided into different categories [13]. Derivatives of imidazole were reported for anti inflammatory, 
analgesic, tuberculostatic, anticancer and antidepressant and microbial and antifungal activities.[13,14].

\section{Experimental \\ Materials}

Maleic anhydride and imidazole were purchased from BDH, dibenzoylperoxide was obtained from Fluka, DMF and dioxane were commercially available and of analytical grade.

\section{Characterization}

Fourier transform infrared (FTIR) spectra were recorded on a Perkin-Elmer spectrophotometer, $4000-400 \mathrm{~cm}^{-1},{ }^{1} \mathrm{H}$ NMR spectra were obtained at $25^{\circ} \mathrm{C}$ on a Bruker AV 400NMR spectrometer samples for ${ }^{1} \mathrm{H}-\mathrm{NMR}$ spectroscopy were prepared by dissolving about $10 \mathrm{mg}$ of products in an appropriate amount of deutrerated DMSO.

Quantitative analysis corresponding to the amount of pendant carboxyl groups incorporated onto prepared polyamic acid, by titration method as follows: $0.1 \mathrm{~g}$. of prepared polymaleamic acid was put in $20 \mathrm{ml}$ of dioxane, then the solution was directly titrated to phenolphthalein end-point using sodium hydroxide $(0.02 \mathrm{M})$ in methanol. Result were expressed as the content of carboxyl groups which is defined as the mole percentage of the polymaleamic acid.

Thermal analysis was performed using TGA instruments and differential scanning calorimeter equipped with a RCS accessory under nitrogen atmosphere, the standard procedure is as follows :- the samples (about $5 \mathrm{mg}$.) were heated and the effect of heat treatment on the crystalline structure of the polymers, a rate of $20{ }^{\circ} \mathrm{C} \mathrm{min}{ }^{-1}$

\section{Preparation of $\mathbf{N}$ - imidazoyl maleamic acid}

In a beaker, $0.5 \mathrm{~g}$. (5mmole) of maleic anhydride was dissolved in $5 \mathrm{ml}$ of dioxane at ambient temperature with rapidly stirring for $1 \mathrm{~h}, 0.5 \mathrm{mmol}$ of dissolved imidazole was added to the mixture. The reaction was continued to the corresponding time at $25{ }^{0} \mathrm{C}$, the white product was formed, filtered and subsequently dried under vacuum.

\section{Polymerization of imidazoyl maleamic acid}

$0.3 \mathrm{~g}$. of prepared monomer was dissolved in $5 \mathrm{ml}$ of dioxane, and $0.05 \%$ weight of dibenzoyl peroxide was added, under nitrogen atmosphere, the polymerization tube was covered, heated by water bath at $90^{\circ} \mathrm{C}$ about 25 mins. The colorless polymer was obtained with $85 \%$ yield with m.p about $275-285^{\circ} \mathrm{C}$

\section{Swelling studies}

Dynamic swelling studies of polymer made as follows:-

Polymer was swollen in solution with $\mathrm{pH} 7$ at $37{ }^{\circ} \mathrm{C}$ to determine the parameters of swelling and diffusion. Swollen gels removed from the water bath at regular intervals were dried superficially with filter paper. Weighted and placed in the same bath.

To investigate the time -dependent swelling behavior of polymer in solutions with $\mathrm{pH} 7$, we performed dynamic swelling studies. The swelling $\mathrm{S} \%$ is calculated from the following relation:-

$$
\mathrm{S} \%=\left(\mathrm{M}_{1}-\mathrm{M}_{0}\right) / \mathrm{M}_{0} \times 100
$$

Where:- $\mathrm{M}_{0}$ is the mass of dry polymer at time 0 .

$\mathrm{M}_{1}$ is the mass of swollen polymer at time $\mathrm{t}$.

Swelling curves of polymer in water with $\mathrm{pH} 7$ at $37{ }^{\circ} \mathrm{C}$ shown in Fig. (3).

\section{Studying of controlled release of polymer}

A mixture of $50: 50 \mathrm{ml}$ of polymer and solution in ( $\mathrm{pH} 4, \mathrm{pH} 10)$ was kept in a cylinder $100 \mathrm{mg}$ of polymer was added, kept at $37 \mathrm{C}^{0}$ without stirring, release sample was periodically drown with an analysis by UV spectra at $330 \mathrm{~nm}$ to determine the amount of release imidazole. A calibration curve was constructed with soft ware built in the computerized UV photometer and the controlled release polymer were carried out in different $\mathrm{pH}$ value $(\mathrm{pH} 4, \mathrm{pH} 10)$ at $37{ }^{\circ} \mathrm{C}$.

\section{Results and Discussion}

In this study the polymer was prepared containing imidazole units as pendant groups the poly (maleamic acid) which acted as drug or antimicrobial agents. The following reaction was explained as below:- 


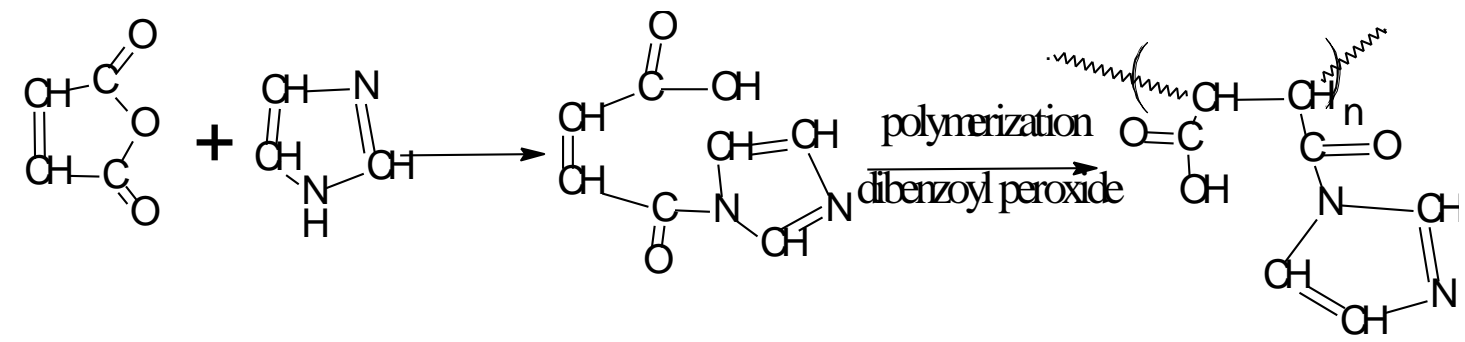

To acid in the structural elucidation of poly(imidazoyl maleamic acid) which functionalization chemistry, with carboxyl groups and imidazole groups along the backbone was analyzed using FTIR spectroscopy, and assignments for the characteristic groups were developed FTIR spectra of prepared polymer is given in Fig. (2) a new band appeared at $1710 \mathrm{~cm}^{-1}$ which confirmed the presence of carboxyl groups and the absorption of $\mathrm{OH}$ carboxylic was appeared at $3450-2962 \mathrm{~cm}^{-1}$ with comparing with Fig. (1) of imidazole alone.

Supporting evidence for the structural elucidation was revealed by ${ }^{1} \mathrm{H}$ NMR analysis, Fig. (5) indicated the content of protons at $2.6 \mathrm{ppm}$ are assigned to $-\mathrm{CH}-\mathrm{CH}-$ of succinamic and the $\mathrm{CH}$ of imidazole was appeared at 7-8 $\mathrm{ppm}$ in addition, the undetectable resonance of protons in the $\mathrm{COOH}$ may be due to the formation of hydrogen bonding between inter-or intramolecules and the proton of carboxylic acid was appear at $9.3 \mathrm{ppm}$.

\section{Thermal Analysis}

In this new prepared polymer which containing imidazole groups, in attempt to understand the link between the incorporation of functional groups and the crystallization of poly maleamic acid was investigated by DSC.

The sample subjected at $300{ }^{\circ} \mathrm{C}$ and kept at this temperature for $5 \mathrm{~min}$ then cooling to $50{ }^{0} \mathrm{C}$, and finally reheating from $50{ }^{0} \mathrm{C}$ to $300{ }^{0} \mathrm{C}$, both heating and cooling rates are $20{ }^{0} \mathrm{C} \mathrm{min}{ }^{-1}$, the crystallization endothermic of polymer occurs at the highest crystallization temperature $\left(\mathrm{T}_{\mathrm{c}}\right)$ and has the sharpest crystallization exothermic.

Table (1) lists the weight loss \% of polymer through different temperature and $\mathrm{T}_{\mathrm{m}}$ of polymer sample is about $280{ }^{0} \mathrm{C}$, this indicated the presence of imidazole group which may explained the effect of substituted groups.
Table (1)

Weight loss \% of prepared polymer.

\begin{tabular}{|c|c|}
\hline Weight loss \% & Temp. ${ }^{\boldsymbol{}}{ }^{\text {C }}$ \\
\hline \hline 15 & 120 \\
\hline 50 & 260 \\
\hline 75 & 280 \\
\hline
\end{tabular}

The glass transition temperature $\left(\mathrm{T}_{\mathrm{g}}\right)$ also helps in understanding the effects of functional groups on the movement of the polymer chains due to the interactions between the acid group as hydrogen bonding.

\section{Controlled bioactive release}

Controlled bioactive release was illustrated in Fig.(4) at $\mathrm{pH} 4,10$ indicated the more hydrolysis in basic medium, this hydrolysis in acidic or basic medium acts as a smart bioactive polymer, that release of imidazole as antimicrobial agent at suitable condition at $37{ }^{0} \mathrm{C}$, the amide is hydrolyzed gradually and this cleavage produces an amine and carboxylic acid polymer. As shown in scheme below: 

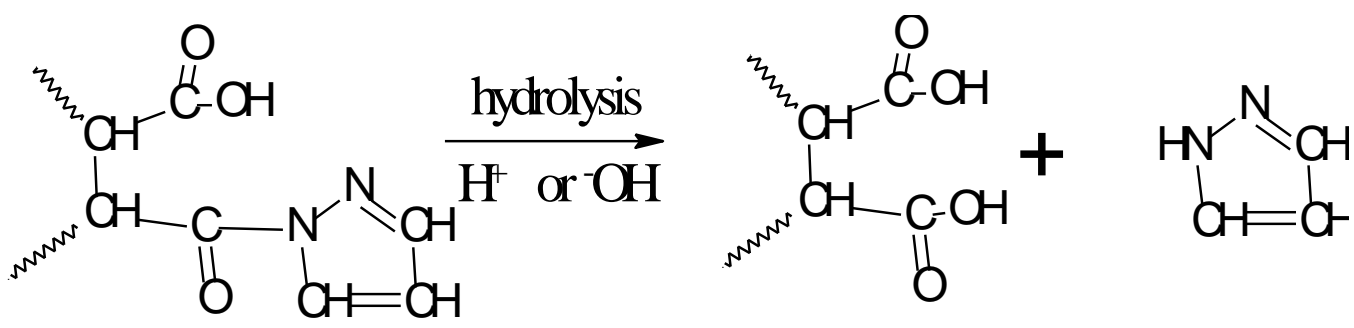

We concluded from this research that the new prepared bioactive polymer and the main goal in this work is investigation of efficient imidazol as a carrier and the effect of $\mathrm{pH}$ values on the imidazole release.

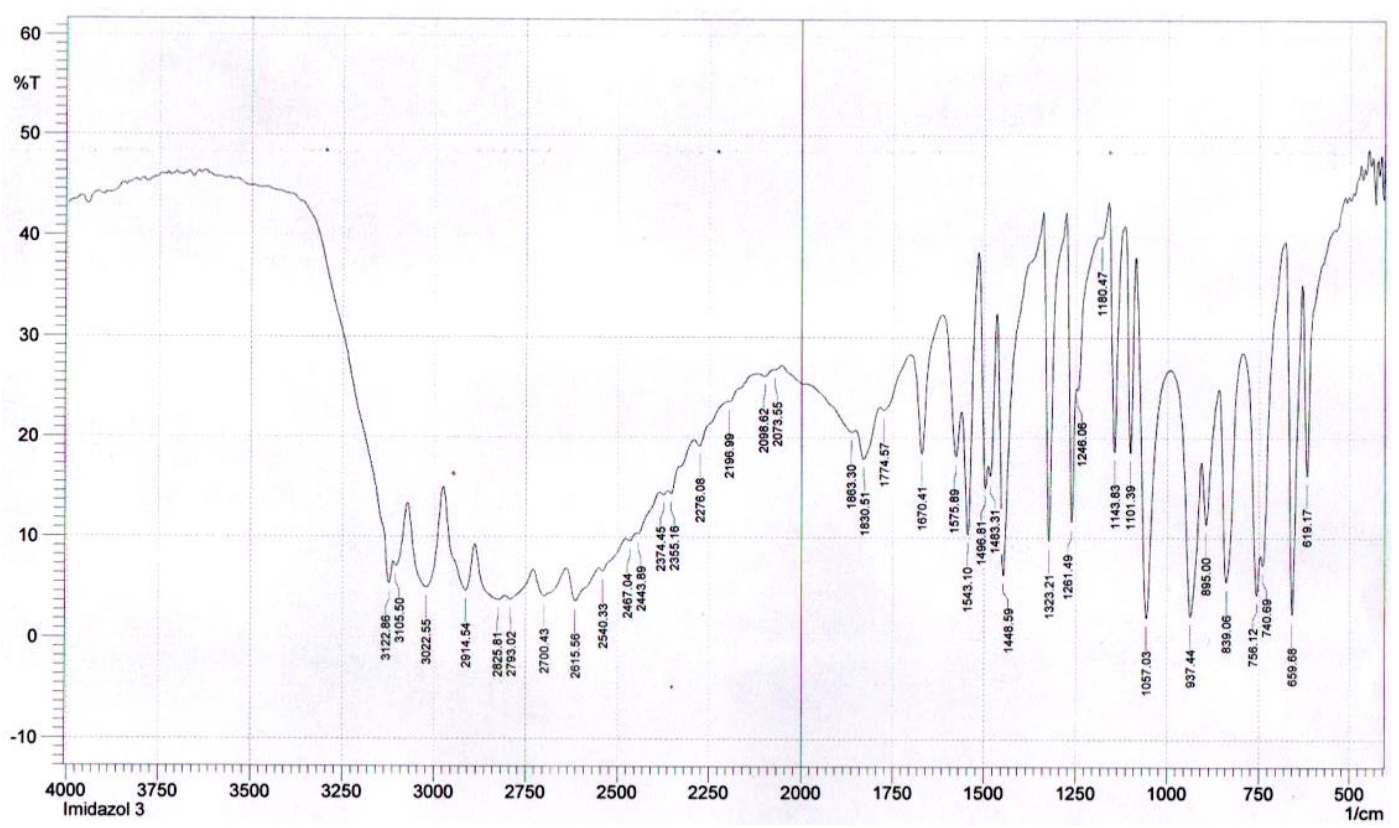

Fig. (1) FTIR spectra of Imidazole.

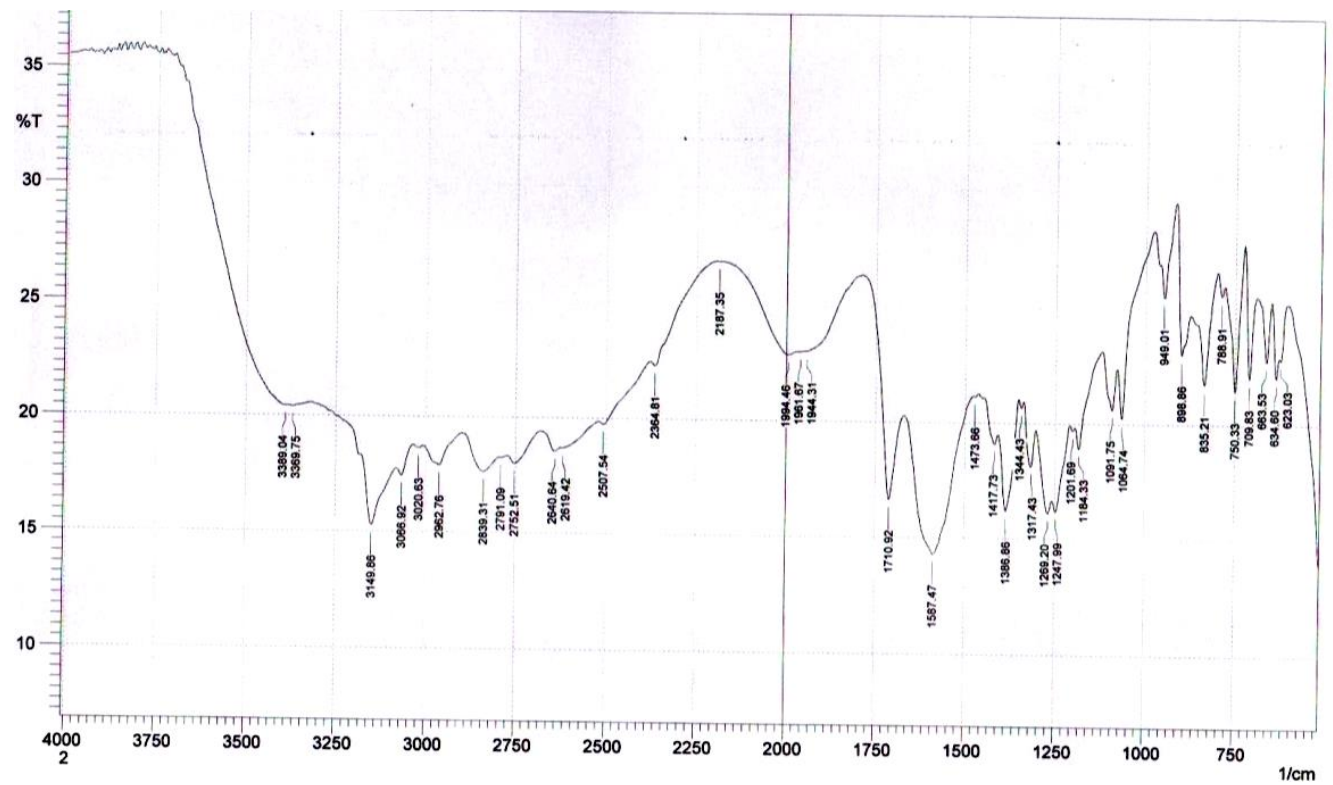

Fig. (2) FTIR spectra of Poly(N-Imidazol maleamic acid). 


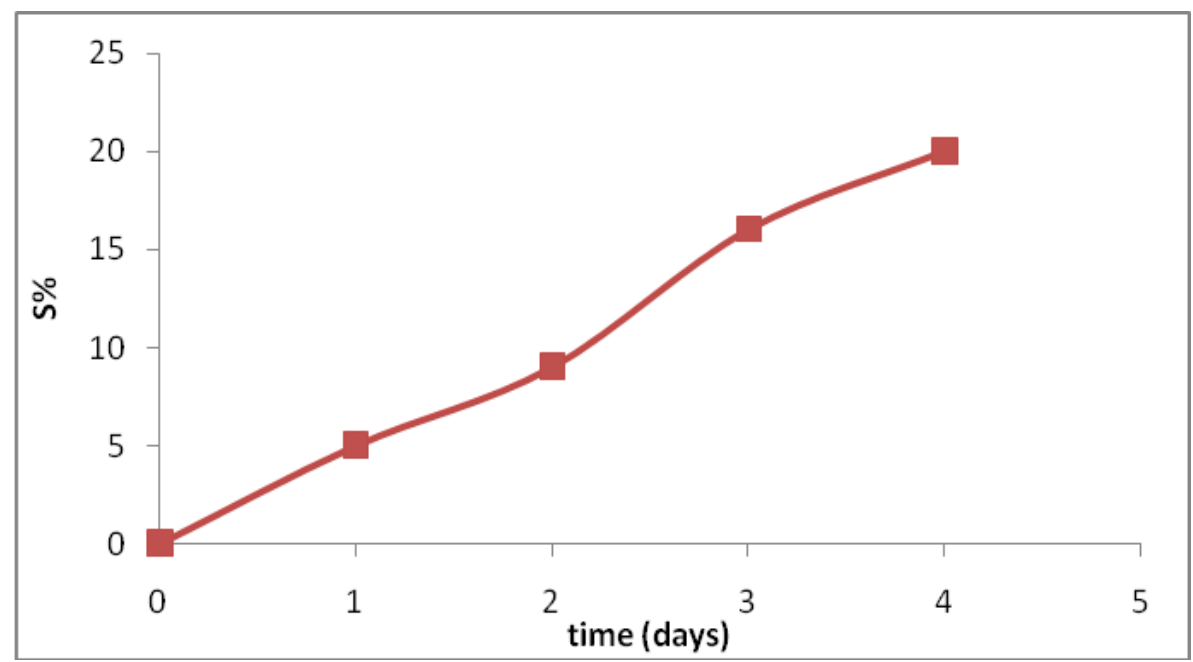

Fig. (3) Swelling curves of polymer in water with $\mathrm{pH} 7$ at $37^{\circ} \mathrm{C}$.

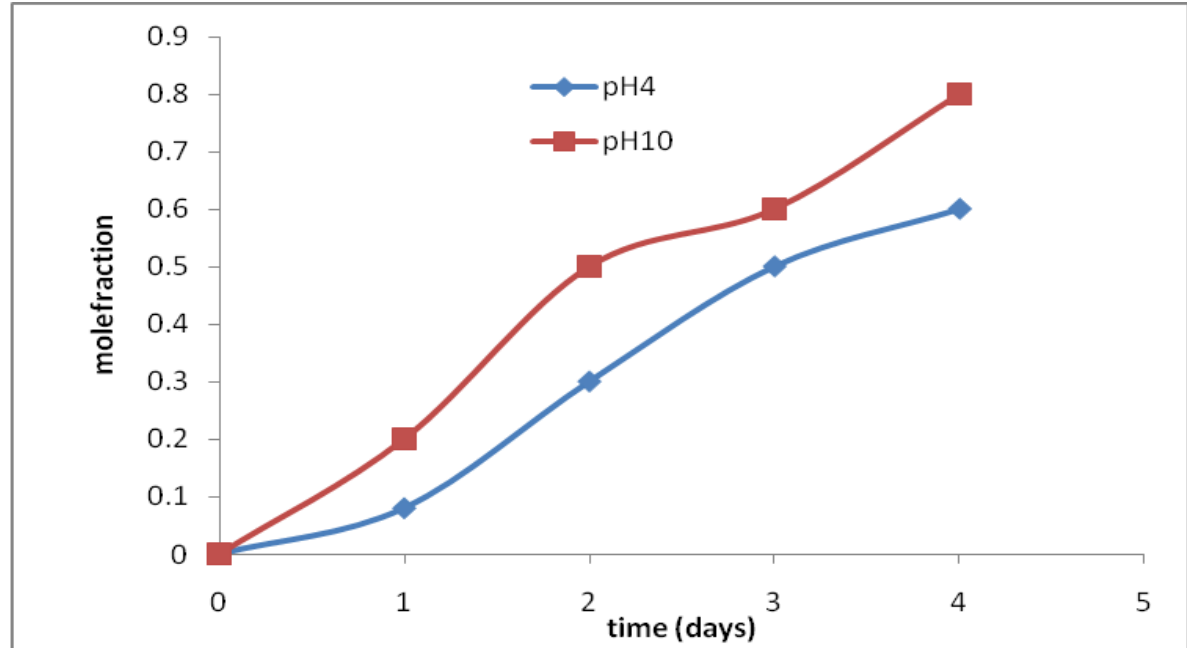

Fig. (4) Controlled release of polymer in different $\mathrm{pH}$ value $(\mathrm{pH} 4, \mathrm{pH} 10)$ at $37^{\circ} \mathrm{C}$.

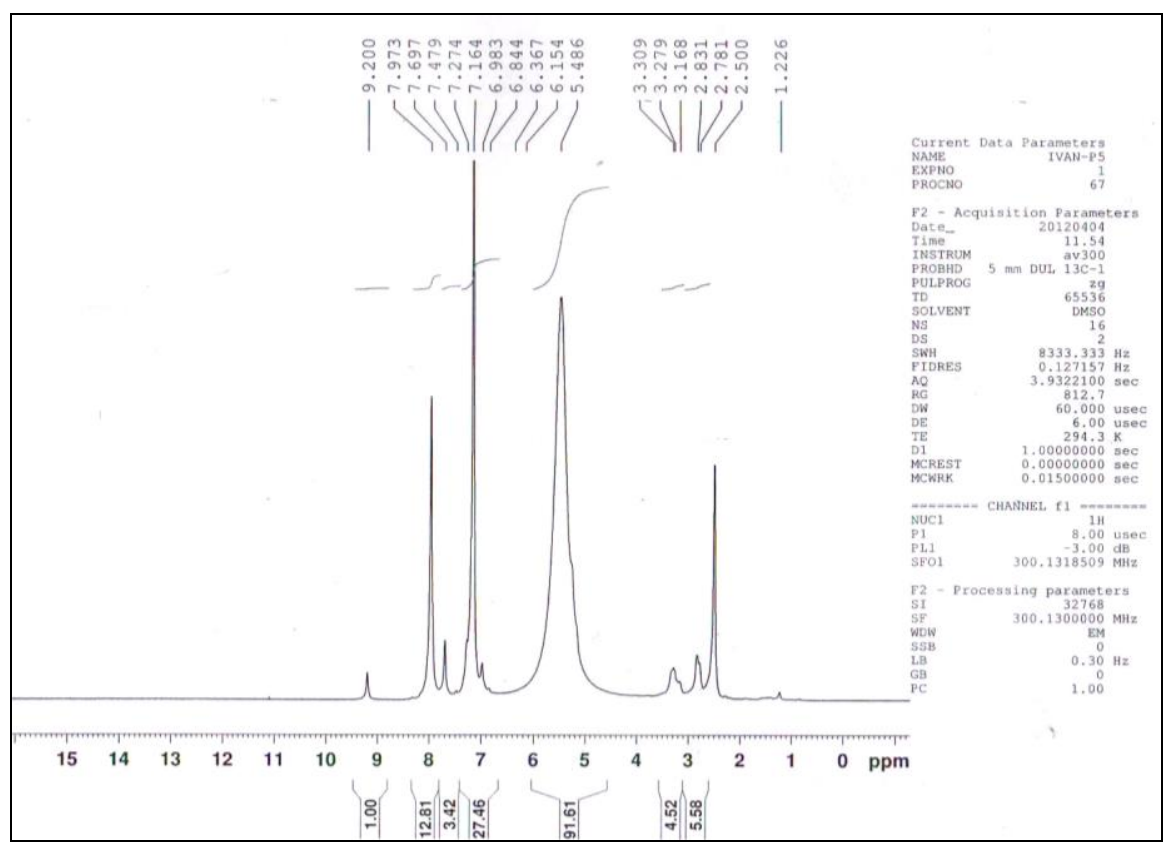

Fig. (5) ${ }^{l} \mathrm{H}$ NMR spectrum of Poly(N-Imidazol maleamic acid). 


\section{References}

[1] Alan R., Rees C., Potts K. "Comprehensive Heterocyclic Chemistry". J. Chem. Educ. Vol.5, p.469-498, 1984.

[2] Grimmett M. ".Imidazole and Benzimidazole Synthesis". J. Chem. Educ, 1999.

[3] Brown E. "Ring Nitrogen and Key Biomolecules". $3^{\text {rd }}$ education, p40-58, Kluwer Academic publishes, 1998.

[4] Pozharskii A. "Heterocycles in Life and Society". John Wiley \& Sons p 276, 1997.

[5] Larock R. "Comprehensive Organic Transformations: A Guide to Functional Group Preparations" 1st Ed.; Wiley-VCH: New York, 1997.

[6] Hakimeleh G, "One step synthesis of imidazol and benzimidazol acryloaromatic nuclosideanaloges" Tetrahedron 58, 1034110344, 2002.

[7] Lopez A., Jeres A "Preparation of N-substituted imidazolles" J. Mol. Cata. A; Che. 124,115-121, 1997.

[8] US patent Arduengo A., Frederick P. "Process for Manufacture of Imidazole", issued 6, 177, 575, 2001.

[9] Leon S., Mutnck H. "Comprehensive Pharmacy Review", $7^{\text {th }}$ edition, p930, 2004.

[10] Richard H. "Veterinary Pharmacology and Therapeutics", $8^{\text {th }}$ edition, p553-586, 2001.

[11] Kim J.M., Ahnk K.D. and Wolff G. Macromol Chem. Phys., 202, 1105, 2001.

[12] Dugas H. "Bioorganic Chemistry", $3^{\text {rd }}$ edition, Springer-verlag, 6, P192. 1996.

[13] Sanjay K., Mali S. and Mishra B. "Synthesis, spectral characterization and biodegradable screening of some novel synthesized imidazoles" International J. No(1) p27-31. 2011.

[13] Domb A. and Maniar M. "Absorbable biopolymers derived from dimer fatty acids" J. Poly. Sci. Part A. Polym.Chem.31 p12751285. 1993.

[14] Constantinos A. and Julia S. "Convenient synthesis of polybrominated imidazole building blocks "ARKIVOC, 4, 101-111, 2007.
حضر في هذا البحث بولي حامض المالي اميك الذي

عوض بالايميدازول كمادة فعالة بايولوجيا، وقد حضر من بن

تفاعل حامض الماليئك اللامائي مع الايميدازول وبفتح حلقة بالية الماليئك اللامائي بواسطة الايميدازول، ثم بلمر حامض المضئ

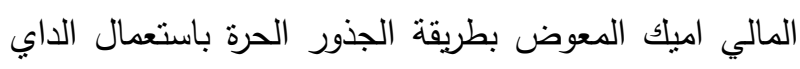

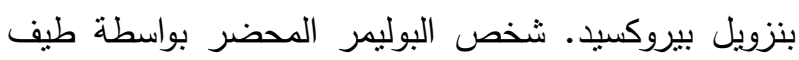
الرنين النووي المغناطيسي ومطياف الاشعة تحت الحمراء والاشعة فوق البنفسجية. درست سرع التحرر المحكم لوحدات

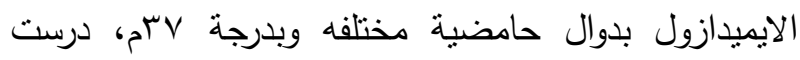
جميع الصفات الفيزياوية للبوليمر المحضر . 